\title{
Workshop model pembelajaran demokrasi guru sekolah dasar di Jawa Tengah
}

Muhamad Taufik Hidayat ${ }^{1, *}$, Albi Arangga ${ }^{1}$, Muhammad Abdur Rohman ${ }^{1}$, Faradiyah Nurul Rahmawati ${ }^{1}$, Rina Ulwiyatus Saadah ${ }^{1}$, Arief Cahyo Uto mo ${ }^{1}$, Muhroji ${ }^{1}$

${ }^{1}$ PGSD, Universitas Muhammadiyah Surakarta, Jalan Ahmad Yani No 1, Pabelan, Kartasura, Surakarta, Indonesia

${ }^{*}$ Korespondensi (e-mail:mt.hidayat@ums.ac.id)

Received:01-June-21; Revised:20-June-21; Accepted:23-June-21

\begin{abstract}
The aim of this community service is to provide a democracy leaming model workshop for elementary school teachers in Central Java. This activity is to socialize and practice the skills of the democratic learning model at the elementary level. In this activity, 26 elementary school teachers participated by online (Zoom Application). This community service is carried out in the form of a workshop with the first stage in the form of lecturing, questions and answers, and discussions. While the next stage is in the form of practice. Based on the implementation of this community service, it can be concluded that: first, th is workshop is able to improve the knowledge and skills of elementary school teachers in Central Java of democracy leaming model. This workshop also produced a video product of the steps of the democracy learning model. This workshop was considered success because all participants participated fully.
\end{abstract}

Keyword: democracy learning model, primary school teachers

\section{Abstrak}

Tujuan yang ing in dicapai melalui kegiatan pengabdian ini adalah memberikan Workshop Model Pembelajaran Demokrasi bagi Guru Sekolah Dasar (SD) di Jawa Tengah. Muara dari kegiatan ini adalah untuk mensosialisasikan sekaligus mempraktekkan keterampilan model pembelajaran demokrasi di tingkat SD. Adapun dalam kegiatan ini diikuti sebanyak 26 guru SD secara online melalui aplikasi Zoom. Kegiatan pengabdian kepada masyarakat ini dilaksanakan dalam bentuk workshop dengan tahapan pertama berupa informasi, tanya jawab, dan diskusi. Sementara tahapan berikutnya berupa latihan dan praktek. Berdasarkan pelaksanaan kegiatan pengabdian masyarakat ini, dapat ditarik kesimpulan bahwa: pertama, workshop ini mampu men ingkatkan pengetahuan dan keterampilan peserta guru-guru SD di di Jawa Tengah. Lokakarya ini juga menghasilkan produk video langkah-langkah Model Pembelajaran Demokrasi. Workshop ini dianggap berhasil karena seluruh peserta berpatisipasi secara penuh.

Kata kunci: model pembelajaran demokrasi, guru sekolah dasar How to cite: Hidayat, M. T., Arangga, A., Rohman, M. A., Rahmawati, F. N., Saadah, R. U., Utomo, A. C., \& Muhroji, M. (2021). Workshop model pembelajaran demokrasi guru sekolah dasar di Jawa Tengah. Penamas: Journal of Community Service, 1(1), 8-18.

\section{Pendahuluan}

Tingkat demokrasi masyarakat berbanding lurus dengan bagaimana tingkat mendidik para guru yang demokratis. Guru sekolah dasar (SD) memiliki peran penting karena anak pertama kali diajarkan secara fomal nilai-nilai demokrasi seperti keadilan, toleransi, dan sebagainya (Samanci, 2010). Selain itu, siswa SD lebih memperhatikan perilaku guru mereka serta mudah dipengaruhi oleh perilaku guru 
mereka (Kucukahmet, 2009). Dalam hal ini, guru harus mengadopsi sikap dan citacita demokratis di dalam hati mereka untuk menanamkan pemahaman dan cita-cita demokrasi pada siswa mereka (Shechtman, 2002). Namun guru biasanya mengajarkan demokrasi sesuai pandangan, pikiran, keyakinan dan pemahaman mereka sendiri tentang demokrasi (Kocoska, 2009). Oleh karena itu, dapat dikatakan bahwa membentuk sikap, nilai dan perilaku demokratis pada siswa SD sangat dipengaruhi oleh pengetahuan, sikap dan keteram pilan guru SD itu sendiri.

Penelitian terkait pendidikan demokrasi pada calon guru telah beberapa kali dilakukan. Mulai dari pendidikan multikultural sebagai sarana merekonstruksi demokrasi (C. Sleeter, 2008), pendidikan yang relevan secara budaya dalam demokrasi yang beragam (Gay, 2000; Ladson-Billings, 1995; C. E. Sleeter, 2008; Villegas \& Lucas, 2002), serta memusatkan keadilan sosial sebagai tujuan utama (Cochran-Smith, 2004; North, 2009; Picower, 2012; K. M. Zeichner, 2009). Studi lain berkaitan dengan mempersiapkan guru sebagai pendidik demokratis melalui mata kuliah (course) (Harber \& Serf, 2006; Kincheloe, 2004; Leistyna et al., 2004; O’Brien, 2005; Rainer \& Guyton, 1999; Robertson, 2008; Slekar, 2009).

Sementara itu, Adler (2008) secara khusus merinci tren ini dalam pendidikan guru IPS. Beberapa program studi, membingkai mata kuliah sebagai sarana belajar demokrasi bagi calon guru (Journell, 2013), konsepsi awal demokrasi, dan kewarganegaraan (Carr, 2012; Castro, 2013). Penelitian lain meneliti upaya programatik untuk mempromosikan pendidikan kewarganegaraan multikultural (Mathews \& Dilworth, 2008). Selain itu, di tingkat dasar, Silva \& Mason (2003) meneliti bagaimana pendekatan yang berfokus secara konseptual untuk pendidikan kewarganegaraan dasar dapat meningkatkan pengetahuan untuk calon guru. Penelitian tentang PPL dalam pendidikan IPS sebagai ruang untuk mengembangkan keyakinan calon guru tentang keberagaman (Adler, 2008; Sunal et al., 2009; K. Zeichner, 2010).

Berdasarkan hasil wawancara singkat dengan beberapa guruSD di Jawa Tengah, diperoleh beberapa informasi berkaitan dengan belum optimalnya Pendidikan Demokrasi di SD, yaitu sebagai berikut.

1. Pendidikan nilai-nilai demokrasi di tingkat sekolah jarang dilakukan.Jikapun ada, materinya lebih ditekankan pada apa yang ada di kurikulum yang cenderung berupa soal-soal rutin yang ada di buku paket/buku siswa.

2. Sekolah kesulitan dalam mencari model pendidikan yang efektif dan efisien dalam penanaman nilai-nilai demokrasi pada siswa SD. Guru-guru beralasan tidak menguasai Pendidikan demokrasi dengan baik dan juga kesulitan mendapatkan dan mengembangkan materi untuk penanaman nilai-nilai demokrasi.

Sebagai salah satu lembaga pendidikan yang mendidik calon tenaga edukatif, Universitas Muhammadiyah Surakarta perlu berperan serta dalam penanaman nilainilai demkrasi. Salah satu program yang perlu dilakukan adalah pelatihan model Pendidikan demokrasi pada guru SD di Jawa Tengah. 
Pembelajaran di SD merupakan salah satu tahap pembelajaran yang penting karena akan berpengaruh pada pembelajaran di jenjang berikutnya. Pembelajaran di SD adalah bagian dari inti sari dalam menanamkan karakters siswa.

Dari analisis di atas pada dasamya guru SD cukup kesulitan dalam menanamkan nilai-nilai demokrasi pada siswa. Hal ini dikarenakan, masih minimnya pengetahuan guru SD terkait nilai-nilai demokrasi, pendidikan demokrasi, serta model pendidikannya. Dari latar belakang tersebut, maka rumusan masalah yang dapat ditarik adalah bagaimana bentuk program workshop model pendidikan demokrasi pada guru SD di Jawa Tengah?

Tujuan utama dari program pengabdian ini adalah: (1). Memberikan pengetahuan terhadap guru-guru SD di Jawa Tengahterkait nilai-nilai demokrasi dan model pendidikan demokrasi. (2). Memberikan pendampingan terhadap guru-guru SD di Jawa Tengah dalam penerapan model Pendidikan Demokrasi di SD.

Hasil kegiatan pengabdian pada masyarakat ini akan memberikan kontribusi positif terhadap usaha peningkatan kualitas pendidikan, khususnya di jenjang SD. Secara eksplisit kontribusi hasil kegiatan pengabdian masyarakat ini dapat dijabarkan sebagai berikut.

1. Para guru SD di Jawa Tengah memperoleh pendalaman pengetahuan tentang langkah-langkah model pembelajaran demokrasi sehingga dapat meningkatkan kemampuan pada aspek pembelajaran yang belum maksimal.

2. Meningkatkan kualitas pendidikan demokrasi di SD Jawa Tengah.

3. Mendukung suksesnya program pemerintah dalam bidang Pendidikan karakter.

4. Terjalinnya kerjasama yang saling menguntungkan antara sekolah dengan Universitas Muhammadiyah Surakarta dalam rangka peningkatkan profesionalisme guru.

\section{Metode Pengabdian}

\section{Khalayak Sasaran}

Khalayak sasaran kegiatan ini adalah guru-guru SD di Jawa Tengah bejumlah 26 orang. Tim pelaksana akan melakukan sosialisasi dan promosi kegiatan pengabdian ini melalui media sosial dan email resmi SD di Jawa Tengah. Guru-guru tersebut akan secara sukarela mendaftarkan diri dalam kegiatan pengabdian dengan menghubungi pihak penyelenggara.

\section{Tahap Persiapan}

Tujuan yang ingin dicapai melalui kegiatan pengabdian ini adalah memberikan workshop model pembelajaran demokrasi guru SD di Jawa Tengah. Adapun rincian rencana pelaksanaan sosialisasi program workshop ini sebagai berikut:

Waktu : Minggu, 13 Juni 2021

Tempat : Virtual Meeting dengan tautan https://us02web.zoom .us///9331007359

Peserta : Guru SD di Jawa Tengah 
Materi :

1) Urgensi Model Pembelajaran Demokrasi

2) Praktik Model Pembelajaran Demokrasi (terdapat 27 langkah)

Bahan yang dibutuhkan antara lain:

1) Materi tentang model pembalajaran demokrasi

2) Materi tentang langkah-langkah penerapan model pembelajaran demokrasi

\section{Tahap Pelaksanaan}

Workshop ini terbagi dalam sekali pertemuan dalam Virtual Meeting dengan tautan https://us02web.zoom.us/j/9331007359. Persiapan alat dan bahan selama workshop berlangsung, perlu dipersiapkan alat dan bahan. Alat yang digunakan adalah materi, alat tulis, laptop/handphone, serta koneksi Internet.

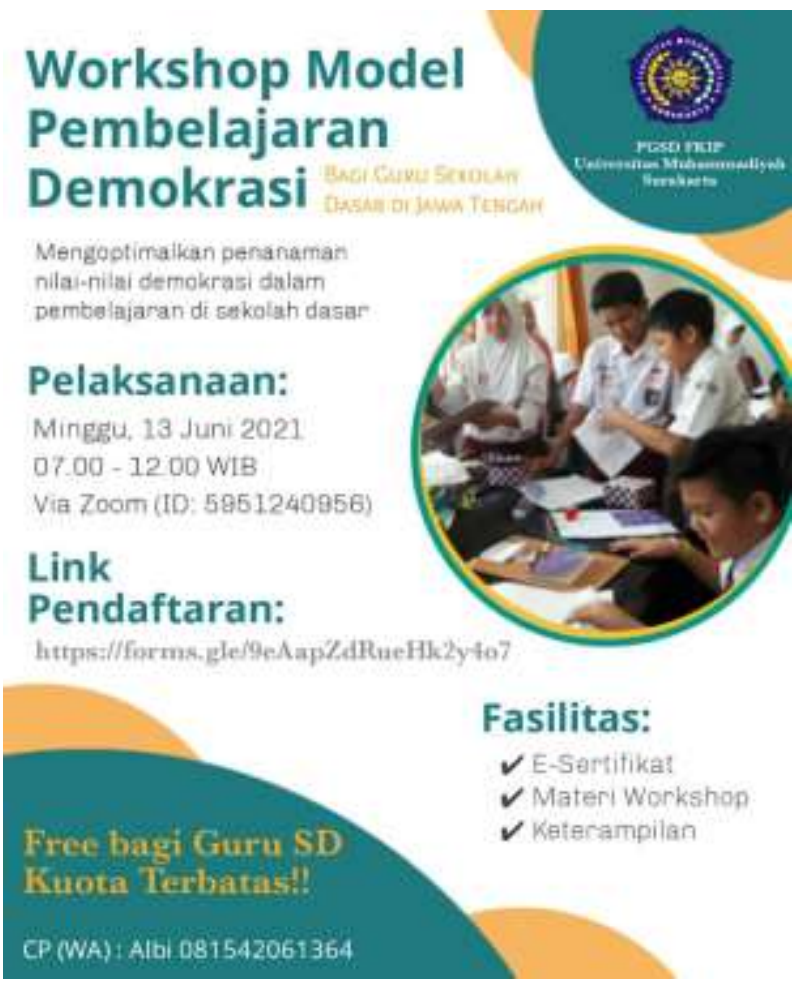

Gambar 1. Pamflet Kegiatan Workshop Model Pem belajaran Demokrasi

Tabel 1 Pelaksanaan Workshop Model Pembelajaran Demokrasi

\begin{tabular}{cl}
\hline No & \multicolumn{1}{c}{ Materi Kegiatan } \\
\hline 1 & Materi Umum (Sambutan, Selayang Pandang, dan Pengantar \\
& Materi) \\
2. & Praktik Mengajar Model Pembelajaran Demokrasi \\
& - Langkah 1-7 \\
& - Langkah 8-14 \\
& - Langkah 14-21 \\
3 & Pembahasan Pengembangan dan Evaluasi \\
4 & Tugas Mandiri Praktik Model Pembelajaran Demokrasi \\
\hline
\end{tabular}




\section{Evaluasi Pelaksanaan Program}

Pada sesi ini dilakukan tanya jawab atau diskusi mengenai pemasalahanpermasalahan yang dijumpai di lapangan. Setelah itu untuk mengetahui keberhasilan pelaksanaan kegiatan ini, dilakukan evaluasi di akhir pelaksanaan kegiatan, Untuk mengukur keberhasilan kegiatan pengabdian maka diadakan evaluasi.

\section{Hasil Pengabdian}

\section{Sambutan Pengabdian}

Muhamad Taufik Hidayat, M.Pd selaku ketua dari tim pengabdian masyrakat memberikan sambutan kepada semua peserta yang hadir dalam pertemuan virtual Zoom Meeting tentang workshop model pembelajaran demokrasi, serta menyampaiakan terimakasih telah bersedia dan berpatisipasi dalam pelaksanaan kegiatan tersebut. Beliau juga menyampaikan bahwa peserta yang hadir dalam virtual meeting diminta untuk memperhatikan dan meyampaikan pemasalahanpermasalahan yang timbul di tempat mengajar yang dialami oleh setiap peserta.

\section{Selayang Pandang dan Pengantar Materi}

Selayang pandang dan pengantar materi yang diberikan oleh Muhamad Taufik Hidayat, M.Pd beliau menyampaikan tentang asal mula dilaksakan workshop model pembelajaran demokrasi adalah bahwa penanaman nilai-nilai perlu dilakukan sejak dini. Dalam lingkup pendidikan SD, peran guru menjadi penting karena ia adalah ujung utama dalam melakukan kegiatan penanaman nilai-nilai demokrasi. Syarat utama dalam mensukseskan penamanan demokrasi adalah pengetahuan guru mengenai demokrasi. Selain daripada itu, aspek keteram pilan juga menjadi suatu hal diprioritaskan.

Latar belakang masalah yang menjadi inisiasi dalam pengembangan model pembelajaran demokrasi adalah minimnya pengetahuan dan keterampilan, baik calon guru maupun guru yang memiliki tanggungjawab penuh dalam menanamkan nilai-nilai demokrasi dalam pembelajaran di sekolah. Dalam konteks calon guru SD, pengetahuan mengenai demokrasi dirasa minim. Hal ini dilatarbelakangi oleh peran mahasiswa PGSD UMS yang tidak maksimal dalam mengikuti perkuliahan mata kuliah Pendidikan Kewarganegaraan.

Nilai-nilai demokrasi memiliki beragam prinsip. Dalam konteks model pembelajaran demokrasi, terdapat tiga nilai yang menjadi acuan dasar dalam proses pengembangannya, yakni nilai jujur, toleransi dan musyawarah. Ketiga nilai tersebut dianggap penting sebagai cikal bakal suksesnya kehidupan demokrasi di masyarakat. Hal ini dilandasi dengan berbagai peristiwa sosial yang diakibatkan oleh adanya krisis dari ketiga nilai demokrasi tersebut. Model pembelajaran demokrasi dalam proses pengembangannya ditemui beberapa hal, yakni strategi, tantangan, hasil dan pencegahan. Adapun tabel temuan dari beberapa hal terkait yang diantaranya sebagai berikut: 
Tabel 2. Temuan dari beberapa aspek pengembangan model pembelajaran demokrasi

\begin{tabular}{ll}
\hline \multicolumn{1}{c}{ Aspek } & \multicolumn{1}{c}{ Temuan } \\
\hline Strategi & - Keteladanan \\
& - Prosedur/aturan \\
& - Habituasi \\
& - Monitoring \\
& - Kingkungan \\
\hline Hambatan & - Kingkungan luar \\
& - Perbatabilan individu \\
& - Pengetahuan \\
\hline Hasil & - Sikap \\
& - Berilaku \\
\hline Pencegahan & - Kgama \\
&
\end{tabular}

Dari temuan tabel tersebut kemudian menjadi bahan dasar dalam mengembangkan model pembelajaran demokrasi. Keempat aspek tersebut kemudian diolah dan dimanifestasikan dalam berntuk langkah-langkah Model pembelajaran demokrasi. Adapun langkah-langkah tersebut meliputi 27 langkah dalam pelaksanaannya.

\section{Praktik Langkah-Langkah Model Pembelajaran Demokrasi}

Dalam kegiatan workshop model pembelajaran demokrasi terdapat empat instruktur yang menjelaskan beberapa langkah model pembelajaran demokrasi. Setiap instruktur juga mensimulasikan langkah-langkah model pembelajaran demokrasi. Dalam proses pensosialisasian, keempat instrukur juga mengajak semua peserta untuk berpatisipasi serta menyampaikan beberapa masukkan terkait dengan langkah-langkah model pem belajaran demokrasi.

Model pembelajaran demokrasi memiliki 27 langkah dalam proses pelaksanaanya. Dalam setiap langkah pelaksanaannya, terdapat beberapa metode yang beragam. Hal ini dilatarbelakangi bahwa setiap metode pelaksanaanya memiliki fungsi dan tujuan yang beragam dan didasarkan atas analisis kebutuhan pembelajaan di kelas.

Setelah instruktur memberi penjelasan serta mensimulasikan dari setiap langkah-langkah model pembelajara demokrasi, perserta dianjurkan agar turut serta mempraktikan model pembelajaran demokrasi. Adapun secara teknis, instruktur menunjuk salah satu peserta sebagai guru dan peserta yang lain adalah siswa. Instruktur menjelaskan kembali terkait dengan ketentuan-ketentuan nomatif dalam parktik model pembelajaran demokrasi. 


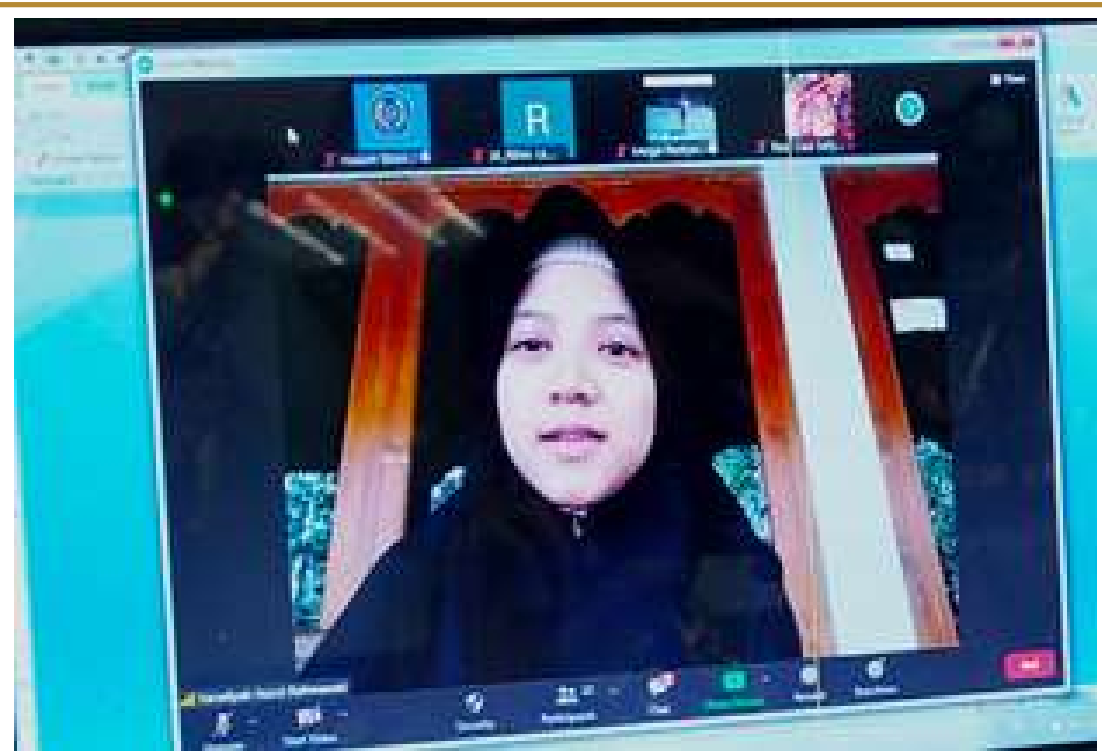

Gambar 2. Salah satu instruktur menjelaskan langkah-langkah model pembelajaran demokrasi

Setelah instruktur memberi penjelasan serta mensimulasikan dari setiap langkahlangkah model pembelajara demokrasi, perserta dianjurkan agar turut serta mempraktikan model pembelajaran demokrasi. Adapun secara teknis, instruktur menunjuk salah satu peserta sebagai guru dan peserta yang lain adalah siswa. Instruktur menjelaskan kembali terkait dengan ketentuan-ketentuan normatif dalam parktik model pembelajaran demokrasi.

Tabel 3. Langkah-langkah model pembelajaran demokrasi

\begin{tabular}{|c|c|c|}
\hline $\begin{array}{c}\text { Sintak } \\
\text { Pengembangan } \\
\text { Pembelajaran } \\
\text { demokrasi }\end{array}$ & Langkah-Langkah & Metode \\
\hline \multirow[t]{6}{*}{$\begin{array}{l}\text { Kegiatan orientasi } \\
\text { pemahaman nilai- } \\
\text { nilai demokrasi }\end{array}$} & $\begin{array}{l}\text { Guru memberikan kajian tentang kejujuran, } \\
\text { toleransi, dan musyawarah. }\end{array}$ & $\begin{array}{l}\text { Pemahaman: } \\
\text { - Kajian Keagamaan } \\
\text { - Kajian Sosial }\end{array}$ \\
\hline & $\begin{array}{l}\text { Guru memberikan apersepsi pembelajaran } \\
\text { mengenai nilai jujur, toleran, dan menghargai } \\
\text { pendapat (musyawarah) sebagai suatu prinsip } \\
\text { dalam demokrasi }\end{array}$ & $\begin{array}{l}\text { Apersepsi } \\
\text { pembelajaran }\end{array}$ \\
\hline & $\begin{array}{l}\text { Guru memberikan pertanyaan kepada siswa } \\
\text { apakah ada yang menemukan barang atau uang. } \\
\text { Siswa diminta mengecek laci masing-masing, } \\
\text { kalau ada sesuatu dicaritahu siapa pemiliknya } \\
\text { lalu dikembalikan. }\end{array}$ & Brainstorming \\
\hline & $\begin{array}{l}\text { Guru memberikan pemahaman terkait cara } \\
\text { musyawarah. }\end{array}$ & Ceramah Partisipatoris \\
\hline & $\begin{array}{l}\text { Guru mengedukasi dalam musyawarah tidak } \\
\text { membawa kepentingan pribadi. }\end{array}$ & \\
\hline & $\begin{array}{l}\text { Siswa diberi masalah yang berkaitan dengan } \\
\text { kejujuran, toleransi, dan musyawarah melalui } \\
\text { video. }\end{array}$ & $\begin{array}{l}\text { Problem Solving } \\
\text { Kolaborasi Jigsaw }\end{array}$ \\
\hline \multirow{3}{*}{$\begin{array}{l}\text { Kegiatan } \\
\text { menginternalisasi } \\
\text { dengan pembiasaan } \\
\text { nilai- nilai demokrasi. }\end{array}$} & $\begin{array}{l}\text { Siswa dibentuk kelompok yang beranggotakan 4- } \\
5 \text { siswa. }\end{array}$ & \\
\hline & $\begin{array}{lcr}\text { Setelah dibentuk kelompok, siswa diminta } \\
\text { bermusyawarah menentukan ketua } \\
\text { sekretaris kelompok (Musyawarah). }\end{array}$ & Pembiasaan \\
\hline & Guru mengawasi setiap jalannya kegiatan & Pengawasan \\
\hline
\end{tabular}




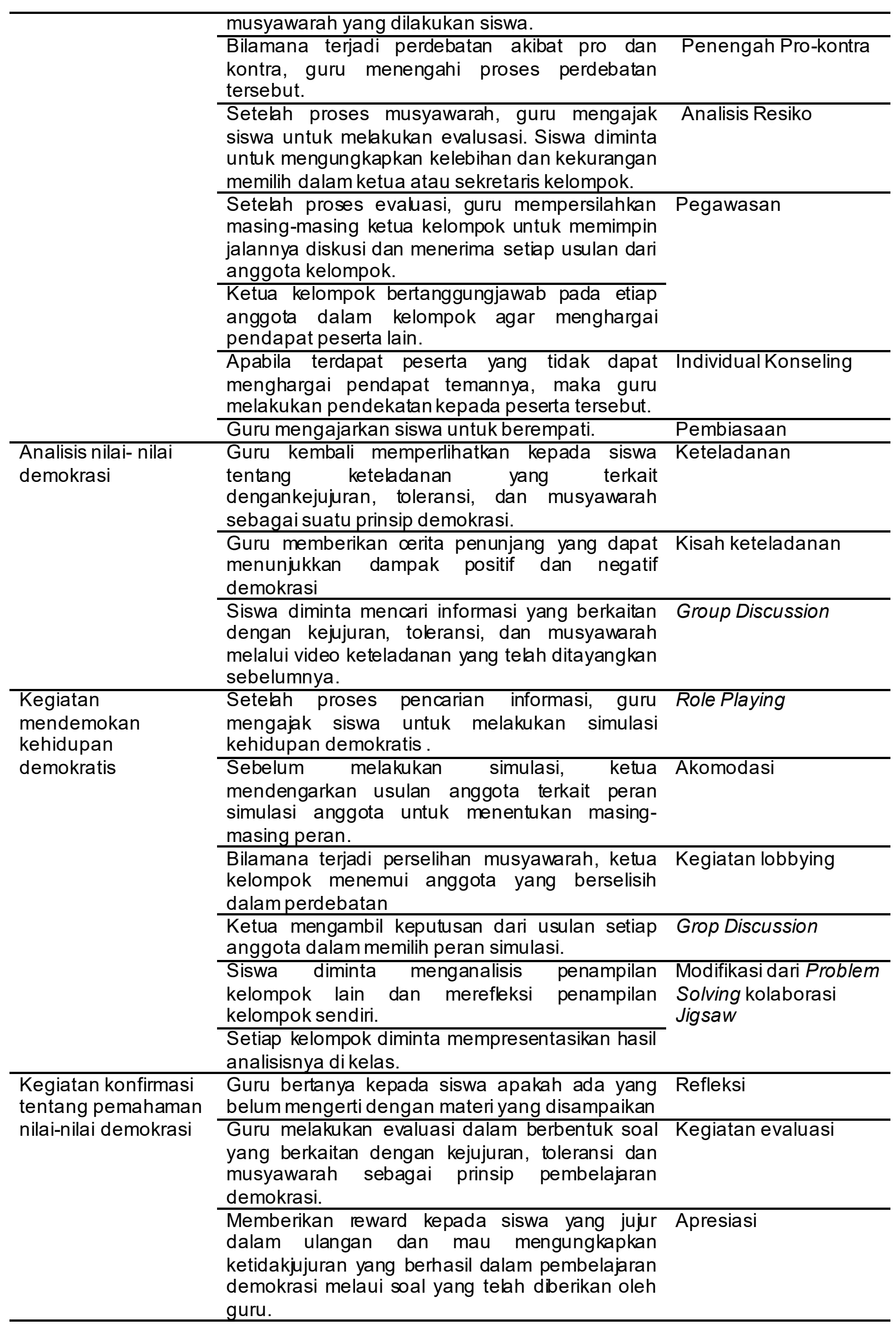


Dalam praktiknya terlihat bahwa beberapa peserta workshop sangat antusias dalam mensimulasikan model pembelajaran demokrasi. Beberapa peserta juga turut aktif dalam mengmukakan pendapat dan dalam beberapa hal ditemui sebuah perdebatan. Peserta yang disimulasikan sebagai guru juga berperan aktif dalam menengahi setiap perbedaan pendapat yang dikemukakan oleh beberapa peserta.

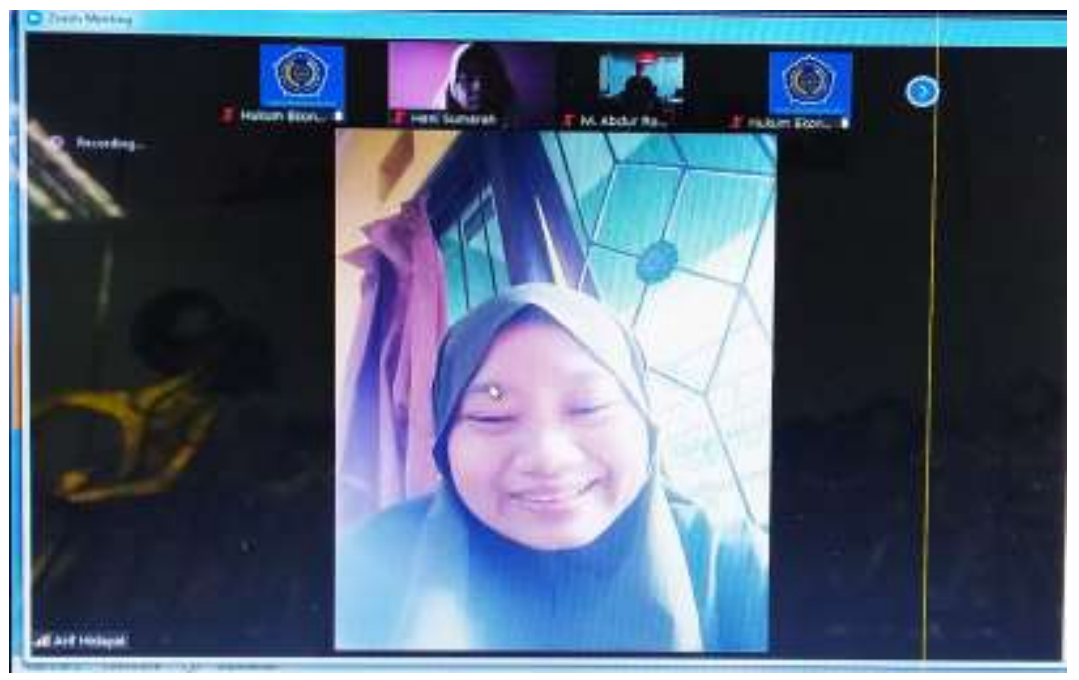

Gambar 3. Salah satu peserta mem praktikan model pembelajaran demokrasi

\section{Kesimpulan}

Hasil dari pelaksanaan workshop model pembelajaran demokrasi menunjukkan bahwa peserta pengabdian sangat antusias dalam mengikuti kegiatan workshop. Hasil Tanya jawab juga banyak menggali permasalahan yang ada di lapangan SD di Jawa Tengah. Adapun rencana tindak lanjt dalam workshop yakni pembentukan grup whatsapp sebagai media diskusi guru dalam pengembangan model pembelajaran demokrasi.

\section{Ucapan Terimakasih}

Ucapan terimakasih sebesar-besarnya penulis haturkan pada Universitas Muhammadiyah Surakarta yang telah memberikan dukungan dana dalam skema program Hibah Integrasi Tridharma FKIP 2021.

\section{Referensi}

Adler, S. A. (2008). 18 The education of social studies teachers. In Handbook of Research in Social Studies Education (pp.329-351.). Routledge.

Carr, P. R. (2012). In Democracy, critical pedagogy and the education of educators. Information Age Publishing, Inc.

Castro, A. J. (2013). What makes a citizen? Critical and multicultural citizenship and preservice teachers' understanding of citizenship skills. Theory Research in Social Education, $41(2)$,

219-246. https://doi.org/10.1080/00933104.2013.783522

Cochran-Smith, M. (2004). Walking the road: race, diversity, and social justice in teachereducation (J. A. Banks (ed.)). Teachers College Press.

Gay, G. (2000). Culturally responsive teaching: theory, research, \& practice (3rd ed.). Teachers College Press. https://www.tcpress.com/culturally-responsive- 
teaching-9780807758762

Harber, C., \& Serf, J. (2006). Teacher education for a democratic society in England and South Africa. Teaching Teacher Education: An International Journal of Research $\quad$ Studies, 22(8), 986-997. https://doi.org/10.1016/j.tate.2006.04.018

Journell, W. (2013). What preservice social studies teachers (don't) know about politics and current events-and why it matters. Theory Research in Social Education, 41(3), 316-351. https://doi.org/10.1080/00933104.2013.812050

Kincheloe, J. L. (2004). The knowledges of teacher education: Developing a critical complex epistemology. Teacher Education Quarterly, 31(1), 49-66.

Kocoska, J. (2009). The student's position in the democratic classroom. Procedia Social and Behavioral Sciences. https://doi.org/10.1016/j.sbspro.2009.01.427

Kucukahmet, L. (2009). Sinif Yonetimi [Classroom management]. Pegem Akademi Yayincilik.

Ladson-Billings, G. (1995). But that's just good teaching! The case for culturally relevant pedagogy. Theory Into Practice, 34(3), 159-165. https://doi.org/10.1080/00405849509543675

Leistyna, P., Lavandez, M., \& Nelson, T. (2004). Introduction - critical pedagogy: revitalizing and democratizing teacher education. Teacher Education Quarterly, 31(1), 3-15.

Mathews, S. A., \& Dilworth, P. P. (2008). Case studies of preservice teachers' ideas about the role of multicultural citizenship education in social studies. Theory Research in Social Education, 36(4), 356-390. https://doi.org/10.1080/00933104.2008.10473380

North, C. E. (2009). Teaching for social justice? Voices from the front lines (1st ed.). Routledge. https://doi.org/10.4324/9781315631721

O'Brien, L. M. (2005). Social foundations of education and democracy: teacher education for the development of democratically oriented teachers. Educational Foundations, 19(3-4), 33-44.

Picower, B. (2012). Practice what you teach: social justice education in the classroom and the streets. Routledge. https://doi.org/10.4324/9780203118252

Rainer, J., \& Guyton, E. (1999). Democratic practices in teacher education and the elementary classroom. Teaching and Teacher Education, 15(1), 121-132. https://doi.org/10.1016/S0742-051X(98)00039-0

Robertson, E. (2008). Teacher education in a democratic society: leaming and teaching the practices of democratic participation (Handbook of research on teacher education) (M. Cochran-Smith, S. Feiman-Nemser, D. J. Mclntyre, \& K. E. Demers (eds.); 3rd ed.). Routledge. https://doi.org/10.4324/9780203938690.ch3

Samanci, O. (2010). Democracy Education in Elementary Schools. The Social Studies. https://doi.org/10.1080/00377990903285499

Shechtman, Z. (2002). Validation of the democratic teacher belief scale (dtbs). International 
https://doi.org/10.1080/0969594022000027672

Silva, D. Y., \& Mason, T. C. (2003). Developing pedagogical content knowledge for civics in elementary teacher education. Theory Research in Social Education, 31(3), 366-397. https://doi.org/10.1080/00933104.2003.10473230

Sleeter, C. (2008). Equity, democracy, and neoliberal assaults on teacher education. Teaching and Teacher Education. Teaching and Teacher Education, 24(8), 1947-1957. https://doi.org/10.1016/j.tate.2008.04.003

Sleeter, C. E. (2008). Preparing White teachers for diverse students (Handbook of research on teacher education) (M. Cochran-Smith, S. Feiman-Nemser, D. J. Mclntyre, \& K. E. Demers (eds.); Handbook o). Routledge.

Slekar, T. D. (2009). Democracy denied: learning to teach history in elementary school. Teacher Education Quarterly, 36(1), 95-110.

Sunal, C. S., Kelley, L. A., \& Sunal, D. W. (2009). Citizenship education in the elementary classroom: teacher candidates photograph and describe their perceptions. Journal of Social Studies Education, 33(1), 33-70.

Villegas, A. M., \& Lucas, T. (2002). Educating culturally responsive teachers: a coherent approach.SUNY.

Zeichner, K. (2010). Rethinking the connections between campus courses and field experiences in college - and university-based teacher education. Journal of Teacher Education, 61(1-2), 89-99. https://doi.org/10.1177/0022487109347671

Zeichner, K. M. (2009). Teacher education and the struggle for social justice. Routledge.https://doi.org/10.4324/9780203878767 